\title{
EUGENICS AND THE WOMAN QUESTION IN THE WORKS OF SELECTED POLISH CATHOLIC HUMANISTS IN THE PERIOD 1918-1939
}

Summary: In the first half of the $20^{\text {th }}$ century, thinking based on eugenics premises was as common as its critique, which partly resulted from assumption of the perspective of the catholic church by humanists and pedagogues, who built their pedagogical conceptions on social teaching of the Church. The present paper aims at presenting the basic elements of criticism of the eugenics stance from the perspective of Polish catholic educators in the years 1918-1939. Such criticism existed and addressed the fundamental themes characteristic of the Catholic Church's position, but it was executed, among others - and that's interesting - from the perspective of women's “interest". Although within introduction of the eugenics principles was presented within the circles that accepted it as a way of emancipation, within the abovesaid environment was treated as a path of demoralization and degradation of the woman as a person.

Keywords: eugenics, Catholic pedagogy, woman, woman's issue, the interwar period

\section{Introduction}

Most commonly, in popular belief, eugenics is associated with Nazi Germany and the "master race" ideology. Far less people are aware of the importance and popularity of the notion in the $1^{\text {st }}$ half of the $20^{\text {th }}$ century and far less people - of this current's presence in reflections on man and society in Poland of that time. Only recently has the academic world devoted attention to this issue and cast light on

1 Dr Dominika Jagielska - adjunct in Department of High School Pedagogy and the Polish Pedagogical Thought, Institute Of Pedagogy, Jagiellonian University. Address: Instytut Pedagogiki UJ, ul. Batorego 12, 31-135 Kraków; e-mail: dominika.jagielska@uj.edu.pl. 
the basic premises of the ideology, history of the movement, and its social reception worldwide.

The problem is interesting not only from a historical point of view that describes its premises, organisations and associations that promote it, adoption and execution of eugenics-based legal regulations, construction of argumentation by both its advocates and opponents. The social perspective onto that phenomenon seems to the of the utmost importance even today. What topics arouse the most animated discussion that engage various circles, Polish ones included? Among opinions voiced by proponents of various options, solutions to such problems as contraception and its consequences, right to perform abortion and euthanasia, the "in vitro" method of conception, along with terms and conditions or limitations of its use, cloning, crime against women and children (sexual violence especially), there are some that make references to thinking in terms of eugenics. Therefore, addressing the problems of eugenics, presenting the opinions and arguments of both its advocates and opponents, seems to be currently and issue of high social importance.

In the first half of the $20^{\text {th }}$ century, thinking based on eugenics premises was as common as its critique, which partly resulted from assumption of the perspective of the catholic church by humanists and pedagogues, who built their pedagogical conceptions on social teaching of the Church. The present paper aims at presenting the basic elements of criticism of the eugenics stance from the perspective of Polish catholic educators in the years 1918-1939. Such criticism existed and addressed the fundamental themes characteristic of the Catholic Church's position, but it was executed, among others - and that's interesting - from the perspective of women's "interest". Although within introduction of the eugenics principles was presented within the circles that accepted it as a way of emancipation, within the above-said environment was treated as a path of demoralization and degradation of the woman as a person. In this paper, I would like to focus on this characteristic message.

\section{The Eugenics Movement Worldwide and in Poland}

Before I discuss the article's main subject, the phenomenon in question should be presented briefly as a certain movement or social ideology. It will allow for pointing out the basic premises of eugenics, which were then interpreted and evaluated by Polish Catholic educators and humanists.

The origins of activity based on eugenics premises may be found in primitive cultures, in which infanticide and abandonment were a way to rid oneself of sick deformed children exhibiting all sorts of disabilities. It was a matter of survival for the entire group. Also in the ancient times, eugenic thinking and its resulting activities were common. For example, the Spartans allowed only strong and 
healthy men to marry and weak children or baby girls were abandoned in the mountains ${ }^{2}$. Plato's ideal state was based on eugenic principle - special matching of the parents and getting rid of children that were considered unhealthy or useless $^{3}$ - breeding physically and mentally healthy individuals. The increase in social and political importance of Christianity brought an objection to such concepts of society and resulting common practices ${ }^{4}$ - their sinful character resulting from negation of the God's will was pointed out.

Eugenics in its contemporary meaning began to develop in the $19^{\text {th }}$ century as a result of advances in the sciences, general interest in Charles Darwin theory of evolution, and resulting emergence of research on heredity ${ }^{5}$. The father of eugenics is Francis Galton, who formed the basic premises of the conception, assuming that the development of a given civilization depends on the condition of the race creating it. The more outstanding individuals society has, the better are its prospects for survival and future functioning. Such an understanding of the development of human societies resulted in formulation of postulates aimed at preventing race degradation: encouraging healthy and talented individuals to reproduce and limiting reproduction of individual who exhibit all sorts of physical and mental deficits ${ }^{6}$. In other words, according to Galton, the process of evolution of the human species should undergo rational, intentional, and planned control.

With time Galton's concept was gaining popularity in Great Britain and other countries to become an international movement in the early $20^{\text {th }}$ century - which is confirmed by formation of numerous associations and institutions that promoted the eugenics thinking and introduction (or attempted introduction) of laws legalizing actions based on eugenics ${ }^{7}$. At the turn of the $19^{\text {th }}$ and $20^{\text {th }}$ centuries, eugenics became an ideology and then a subject of institutionalised activity of the state ${ }^{8}$. Despite the fact it was initially designed as an academic field that was supposed to deal with the issues of transferring features, the cognitive activity was soon subordinate to practical functions. Its premises were used to achieve the key goal: perfecting the human population'. It comprised of three main fields: 1 ) issues concerning conscious maternity, 2) problems of proper care over the child, and 3) issues of limiting or eliminating fertility of people with biological

2 Michał Musielak, Sterylizacja ludzi ze względów eugenicznych w Stanach Zjednoczonych, Niemczech i w Polsce (1899-1945) (Poznań: Wydawnictwo Poznańskie 2008), 19-22.

3 Platon, Państwo (Kęty: Wydawnictwo Marek Derewiecki 2009).

4 Musielak, Sterylizacja, 22-23.

5 Magdalena Gawin, Rasa i nowoczesność. Historia polskiego ruchu eugenicznego (Warszawa: Wydawnictwo Neriton, Instytut Historii PAN 2003), 25-26; Musielak, Sterylizacja, 23-27.

6 Gawin, Rasa, 26-28.

7 Agata Strządała, Od Galtona do Watsona. Przemiany pojmowania eugeniki w XIX i XX wieku (Opole: Uniwersytet Opolski 2010): 33-35.

8 Ibidem, 33.

9 Ibidem, 35, 43. 
of social deficits ${ }^{10}$. In retrospect, the source of inhumane and non-humanitarian practices most likely lied in subordination of other aspect of the human nature to the biological aspect. They also constituted a prelude to the perception of nation as the race of a certain value from the perspective of its biological and social usefulness, which approach was developed „creatively" in the ideology of the Nazi Germany developing in the 1930s.

In Poland, the eugenics movement also emerged, but it did not manage to have its premises codified through introduction of respective laws. The movement dates back to after the revolution of 1905, when the "Czystość" [Purity] magazine was launched. The periodical brought together circles which promoted health of the Polish nation through a campaign against alcohol addiction and sexual promiscuity, emphasizing the importance of rational reproductive matching, and marriage counselling ${ }^{11}$. After Poland regained independence in 1918, further increase in popularity of the eugenic issues took place in Poland in relation to the spread of the Malthusian and neo-Malthusian concepts ${ }^{12}$. The process resulted in launching associations and organisations whose activity referred to the eugenics principles. The most influential ones included Polskie Towarzystwo Walki z Nierządem i Chorobami Wenerycznymi [Polish Association Against Fornication and STD] established in 1918, which, throughout the interwar period, released a periodical titled "Zagadnienia Rasy z Punktu Widzenia Zdrowia Społecznego" [Problems of Race from the Perspective of Social Health] (later on renamed to "Eugenika Polska" [Polish Eugenics]). The organization changed its name in 1923 to Polskie Towarzystwo Eugeniczne [Polish Eugenics Society]. Its members included Leon Wernic (for many years, the chairman of the Polish Eugenics Society) or Tomasz Janiszewski and Witold Chodźko (the first ministers of health of the independent Poland $)^{13}$. Upon the initiative of the members, attempts to introduce eugenics law, modelled after the contemporary German legal regulations, were made in 1934 and $1935^{14}$.

Thus, we cannot say that the eugenics did not exist within Polish society. To the contrary, it was present within scientific and social discourse, it had its followers, also among the highest social and political ranks, who wanted to legalise its principles in the form of binding laws. However, during the interwar period, these attempts went unsuccessful, most likely due to the role of the Catholic Church in

10 Maciej Zaremba Bielawski, Higieniści. Z dziejów eugeniki (Wołowiec: Wydawnictwo Czarne 2011), 334.

11 Gawin, Rasa, 64-79.

12 Aneta Bołdydrew, „Wpływ maltuzjanizmu i neomaltuzjanizmu na rozwój myśli eugenicznej na przełomie XIX i XX wieku”, in: Eugenika - aspekty społeczne i etyczne, ed. Michał Musielak, Krzysztof Prętki (Poznań: Uniwersytet Medyczny im. Karola Marcinkowskiego w Poznaniu 2013): $13-16$.

13 Musielak, Sterylizacja, 212-222. Gawin, Rasa, 83-91, 100-112.

14 Gawin, Rasa, 249. 
Poland and the station of Polish humanists and educators whose works referred to the social teaching of the Church.

\section{The Political, Social, and Cultural Context of Criticism of the Eugenics Principles in Poland in the Years 1918-1939}

Every concept and theory is created, developed, and criticised within a certain social, political, and cultural environment which forms an crucial context for description, comprehension, and explanation of such an outlook. It is hard to forget that educational concepts of Polish Catholic educators from the years 1918-1939 and beliefs and convictions based on them and concerning the man and society, as well as problems currently valid from such a perspective, existed within a very unique situation which, to a large extent, influenced the way he social reality of that time was perceived. That context - social, political, and cultural - is particularly evident in the works of Stanisław Podoleński ${ }^{15}$, one of the major critics of the eugenics movement. However, it seems that even if it is not expressly voiced in works by other Polish catholic authors, it must have played an important role in them - it created a framework for their everyday and scientific existence.

The basic context-forming factor for the works and opinions expressed by Polish educators in the years 1918-1939 consists in the fact that, as a result of world war I, Poland regained independence after many years of foreign oppression. It was a joyous event celebrated throughout the interwar period. That joy, however, was mixed with awareness of challenges and obstacles the newly formed state had to face - both within the scope of internal relations, organisation of the country's social, political, and economic life, as well as foreign affairs and establishing international relations, which often was a hostile and confrontational (fights for borders, the Polish-Soviet war). What is more, over time, a sense of external threat was becoming more and more widespread - and it was based not only on an emotional reaction related to long-term dependence on other states, but also from observation of the global situation. It was perceived especially in a rapid

15 Stanisław Podoleński (1887-1945), a priest, Jesuit, secondary school teacher, educator publishing both academic works that emphasised the social context of education, and highly educational works for the general reader. He focused on the place of the woman in society, he also expressly voiced his opinions on eugenics and the consequences of adopting its principles. See: Janina Kostkiewicz, Kierunki i koncepcje pedagogiki katolickiej w Polsce 1918-1939 (Kraków: Oficyna Wydawnicza „Impuls” 2013), 399 et al.; Janina Kostkiewicz, „Wychowanie prorodzinne w myśli społeczno-pedagogicznej ks. Stanisława Podoleńskiego TJ”, in: Społeczeństwo, kultura, wychowanie w poglądach polskich jezuitów okresu II Rzeczypospolitej, ed. Stanisław Cieślak SJ, Beata Topij-Stempińska (Kraków: Wydawnictwo WAM, Akademia Ignatianum w Krakowie 2012), 141-168. 
and aggressive development of two great totalitarian ideologies within two powerful neighbours: communism, with its brutality and negation of values, in the Soviet Union and national socialism, based on racist assumptions supported by eugenics and a radical interpretation of the evolution theory, in Germany ${ }^{16}$. Thus, joy and hope for the future intervened with fears and a sense of danger.

A complicated internal situation in Poland constituted a part of the social context. Post-war damage added to that from the partitions period which resulted in increased stratification of society and increasing poverty, especially in the countryside and among unskilled blue-collar workers in the cities. Legal regulation introduced worldwide that allowing for, among others, divorce and abortion, introduction of the eugenics principle related to ongoing laicisation of society, as well as activity of all sorts of organisations and association coming to existence in that period, which, quite often, preached various extreme ideals, were treated by Polish Catholic humanists as crucial problems that required a commentary, an educational message addressed at their co-citizens ${ }^{17}$. Researchers tried to describe, explain and evaluate the ongoing changes from the perspective of their philosophical standing and outlook.

An important part of the context within which Polish Catholic educators of the interwar period were set consisted in the basic dogmas and principles of faith as well as the social teaching of the Church. Although I am unable to discuss these issues in detail in this paper, it is with and interesting to point out some references to eugenics within that scope. During the interwar period, three major documents determining the Church's approach to this subject matter were in force. Two of them were encyclicals by Pope Pius XI: "Divini Illius Magistri" of 1929 and "Casti Conubii" of $1930^{18}$, which the third one was a decree of the Supreme Sacred Congregation of the Holy Office dated $21^{\text {st }}$ March $1932^{19}$.

In the first of the two encyclicals, the Pope criticises one of the eugenics premises, that is a liberal or naturalist understanding of sexual education, which informs without taking into consideration the human nature and gullibility of young people ${ }^{20}$. The latter encyclical features direct references to eugenics. In "Casti Conubii", Pius XI discusses in a general, yet pejorative manner, the premises presented by the eugenics circles. First and foremost, he criticises prohibition of marriage enforced on people who, from the eugenics perspective, may produce offspring of "lesser quality", as well as procedures of voluntary and enforced

16 Kostkiewicz, Kierunki, 401-403.

17 Ibidem, 401-403.

18 Gawin, Rasa, 240-341.

19 Stanisław Podoleński, „Eugenika i ruch eugeniczny”. Przegląd Powszechny 579 (1932): 330.

20 Pius XI, Divini Illius Magistri, avaible online (access: 15 III 2018), http://www.nonpossumus.pl/encykliki/Pius_XI/divini_illius_magistri/IV.php 
sterilisation ${ }^{21}$. Attempts to introduce such solutions result, in his opinion, from a lack of respect for natural human rights: to marry and have children. Certain methods used by the eugenics, such as health counselling for children, promotion of pre-marital abstinence and marital faithfulness, may be acceptable for the Catholics. But all activities beyond that scope negate the dignity and freedom of the human being ${ }^{22}$. Therefore the Supreme Sacred Congregation of the Holy Office in a decree, dated as of $21^{\text {st }}$ March 1932, directly calls for complete rejection of eugenics in its every aspect due to its false assumptions with regard to the man and social life. A Catholic family cannot be built upon its premises, because they are connected to a false image of the $\operatorname{man}^{23}$. Therefore, eugenics not only poses a threat for marriage and the family, but for the essence of the man as created in God's image and likeness.

The political social, and cultural context outlined above that describes certain framework within which Polis Catholic educators in the years 1918-1939 existed seems to be of crucial importance to their scientific work and educational activity. It also opens a field for analysis of the eugenics movement in relation to the female issue - the problems presented above forms certain frames on which criticism of eugenics from the perspective of the Catholic social thinking of the interwar period is built.

\section{Criticism of Eugenics and the Female Issue in the Works of Polish Catholic Educators in the Years 1918-1939}

One of the most fervent critics of the eugenics movement in the years 1918-1939, among others in reference to the female issue, was Stanisław Podoleński. However, some references to the phenomenon may be found in the works of other Polish humanists of the Catholic inclination, made directly or mostly indirectly: in works devoted to the woman and her situation in Polish society.

Let's Begin the discussion of eugenics and the criticism of it by the conservative Catholic circles from the concept adopted by Podoleński. He defines eugenics as "a science on the conditions of improving the physical and spiritual strength of a race (in biological terms) through proper influence on reproduction and offspring" ${ }^{24}$. He describe the difference between the positive (theoretical) and negative (practical) eugenics existing then. The former is to refer to scientific

21 Pius XI, Casti Conubii, avaible online (access: 15 III 2018), http://www.nonpossumus.pl/ encykliki/Pius_XI/casti_connubii/II.php

22 Ibidem.

23 Podoleński, „Eugenika i ruch”, 330.

24 Stanisław Podoleński, „Projekt polskiej Ustawy Eugenicznej”. Przegląd Powszechny 204 (1934): 387. 
theories of inheritance and human development, study the biological and social conditions that have a favourable or unfavourable impact on human reproduction and offspring. The negative eugenics, on the other hand, uses results obtained from research to formulate certain guidelines and advice, introduce legal regulations based on them with regard to: limitation of marriage between people with biological or social deficits (problem of pre-marital certificates), approval of abortion, contraception, and voluntary or enforced sterilization of persons considered to be of little value ${ }^{25}$.

In his discussion of the basic issues concerning the eugenics movement and its related scientific approach and outlook, Podoleński negate nor Galton's, the creator of this current of interpreting reality, nor his follower's, who continued and unravelled his concept, noble motivation. He emphasizes that the basic aim of eugenics is to perfect the human kind and prevent the spread of degeneration of $\operatorname{man}^{26}$. The popularity of this way of thinking is partly understandable because of the worsening problems of humanity: health issues in boys and working men who lived in poor conditions, the spread of occupational and contagious diseases, alcohol addiction, the moral crisis, etc. However, the method of execution, the methods proposed by the eugenics movement, must arouse doubts if not objection ${ }^{27}$. It is true that some Christian circles adopt it as a whole and interpret it as an approach promoting consideration of responsibility related to conception of a new life - but a majority of methods proposed by advocates of eugenics are inacceptable to Catholics ${ }^{28}$. Therefore, if what is referred to as positive or theoretical eugenics may be accepted in part by Catholic educators as long as it is related to "philosophical bias", practical or negative eugenics, according to Podoleński, should be rejected as a programme contradictory to the basic human rights and needs ${ }^{29}$.

From the formal perspective, the basic, Podoleński lists three general reservations against eugenics. These are:

- lack of theoretical certainty of the eugenics principle in its scientific aspect;

- peremptory character of its assumptions and their resulting programmes of improvement of society as well as urging the pace of introducing thereof ${ }^{30}$;

25 Idem, „Eugenika dzisiejsza, jej drogi i bezdroża”. Przegląd Powszechny 194 (1932): 166-186; idem, „Eugenika i ruch”, 327-329; idem, „Etyka katolicka a eugenika i medycyna”. Przegląd Powszechny 214 (1937): 195.

26 Idem, „Eugenika i ruch”, 320.

27 Ibidem, 320-325.

28 Ibidem, 329.

29 Idem, „Etyka katolicka”, 195-199; idem, „Eugenika i ruch”, 329 et al.

30 Idem, „Eugenika dzisiejsza”, 179-181. 
- possibility of abuse in relations to introduction of programmes based on its premises (based on experiences related to the introduction of sterilization laws in Germany in 1930s) ${ }^{31}$.

In his discussion on the subject, similarly to other authors publishing in the years 1918-1939 who criticised the eugenics principle, he points mostly to arguments related to the second and the third charge, trying to point to the consequences of adoption of eugenics way of thinking for the man and his life, within a certain scope, in particular for women. He leaves the decision on the first issue up to future developments in science, advising care when it comes to adoption of theses not yet fully confirmed by science.

What does the criticism of eugenics in the works of Polish Catholic humanists refer to specifically? What are its arguments? Finally, how do these arguments refer to the social position of women? While trying to answer these questions, we need to tackle several issues, first and foremost the problems of sexual education and preparation for family life, sterilization of the "lesser quality" individuals, and conscious maternity (problems of abortion and contraception). These are the areas that the eugenics focuses on and these form the baseline for criticism from humanists representing the conservative outlook, who published in the interwar period.

The first are that requires a description is the problem of sexual education and preparation for marriage. A majority of the those advocating the introduction of the eugenics principle into the social life appreciate the role of a lasting marriage and family. However, according to Catholic humanists of the interwar period, this does not result from acknowledgement of the inborn dignity of the family, its sacramental value, or its importance to society, but from utilitarian reasons. The eugenics perceive the family more as a useful institution which enables birth control and provision of best possible care over the minors - what is important within the existing social reality of that times. This means that changes within the social reality may lead to withdrawal of support for the family as the only accepted form of man-women relationship ${ }^{32}$. In other words, the eugenics perceive marriage and family as one of the possible choices within the range of relationships serving the upbringing of children. An option suitable within a given time and place framework may not be universally suitable - which, from the perspective of Catholic social teaching, is inacceptable.

Different approaches to family are also evident in proposal concerning education - especially sexual education. From the perspective of Catholic humanists, "eugenics does not appreciate such an important factor in shaping a young man

31 Idem, „Ustawa sterylizacyjna w Niemczech”. Przegląd Powszechny 201 (1934): 61.
32 Idem, „Eugenika dzisiejsza”, 168-169. 
as family education, it ignores the spiritual, supernatural factor" ${ }^{\prime 3}$. It thus treats education, including sexual education, naturalistically, paying too much attention to the biological aspect of the man's existence in the world. For Catholic humanists, sexual awareness is one but not the only one way to prepare people for marriage and a constituent of education of children and young adults. As such, it is necessary - but it shouldn't be executed neither too naturalistically nor in a vulgar way, neither through moralizing nor mentoring ${ }^{34}$. Persons obligated to introduce young people into the problems of sexuality are the parents, the mother in particular ${ }^{35}$ - only if they are unable, for some reasons, to do so, an educator may take over ${ }^{36}$. Proper home education within the field of preparation for marriage may be supplemented with properly prepared literature and pre-marital courses, as well as Catholic counselling centres which help brides and grooms and young spouses solve their problems ${ }^{37}$.

On the other hand, sexual education proposed by the advocates of eugenics is usually run in larger groups, in a public manner, in a way too crude or realistic, without consideration for the delicate nature of the problem. It encourages involvement in sexual practices to a larger extent than it teaches abstinence. It may, just like distribution of pornography, lead to building a general atmosphere of sexual anxiety within society, which may result in a loosening morals, increase in sexual crime rates, occurrence in obstacles in the development of young people, especially within the spiritual aspect ${ }^{38}$. This results from, among others, introduction of information on and encouragement to use artificial contraceptives and if necessary - abortion into the teaching content of sexual education ${ }^{39}$.

Conclusion of marriage is connected to the problem of pre-marital certificates proposed by the advocates of eugenics as a tool for verification of health of people wishing to get married. Making the right to marry dependent on obtaining

33 Witold Bałachowski, Zasady i ideał wychowania rodzinnego (Poznań: Czcionkami Drukarni Wydawniczej Fr. Krajna Spółka z o.o. w Poznaniu 1937), 6.

34 Zdzisław Goliński, „Walka Kościoła z pornografią”. Prą 36 (1938): 308-310; Stanisław Podoleński, Rozwód a zdrowie narodu (Kraków: 1926), 232-234; T.Cz., „Zagadnienia seksualne w życiu religijnym". Miesięcznik Katechetyczny i Wychowawczy XXV (1936): 203.

35 A.N., „Ku odrodzeniu rodziny”. Przewodnik Społeczny 2 (1929): 67-69; Andrzej Niesiołowski, „Kryzys rodziny nowoczesnej i jego przyczyny”, in: Rodzina. Pamiętnik I Katolickiego Studium o Rodzinie w Poznaniu, w dn. 2-6 września 1935 (Poznań: Naczelny Instytut Akcji Katolickiej 1936): 6; Henryk Weryński, Na progu uświadomienia. Wskazówki dla matek i wychowawców (Poznań - Warszawa - Wilno - Lublin: Nakład Księgarni Św. Wojciecha 1930), 5-10; Podoleński, Rozwód, $242-$ 245; T.Cz., „Zagadnienia”, 204.

36 Weryński, Na progu, 1-2.

37 Stanisław Podoleński, „Wychowanie seksualne młodzieży i przygotowanie do małżeństwa”, in: Wychowanie chrześcijańskie jako problem duszpasterski (praca zbiorowa) (Kielce: Nakładem „Przeglądu Homiletycznego" 1934), 90.

38 Zdzisław Papierkowski, „Przepisy prawne dotyczące pornografii”. Prąd 37 (1939): 102-103; Goliński, „Walka”, 315.

39 Which I shall elaborate on later on. 
a special medical certificate on one's health condition included in a draft of a sterilisation bill proposed by Polskie Towarzystwo Eugeniczne ${ }^{40}$ was supposed to help to limit marriage and reproduction rates among the ill - and thus lead to improvement of the race. From the perspective of Catholic humanists, such certificates are a controversial issue - due to the eugenics origin of the idea on one side, but also due to the fact that it acknowledged the importance of health of brides and grooms as conditioning their fitness for their future life together and having offspring ${ }^{41}$. Podoleński attempts to reach compromise and assumes that the best way to utilize pre-marital certificates is to leave the decision up to the future spouses and their families. He is in favour of taking medical tests before the wedding - they would allow the bride and groom to avoid surprises or tragedies even after they enter into marriage and it would be an expression of simple honesty towards one another, therefore he proposes that pre-marital certificates should be a general procedure. $\mathrm{Bu}$ the final decision concerning conclusion of marriage should be up to the future spouses and he emphasizes that the state should not interfere in any way (for example though introduction of a formal ban on marriage if a specific illness exists ${ }^{42}$. Such an approach would enable misuse of such a tool by the state and it would have an impact on the number of informal relationships and thus deterioration of the national moral standards - it would be far too great an interference of the state in the citizens' private lives ${ }^{43}$. Confronting this proposal of the proponents of the eugenics concept, a representative of the Catholic standpoint takes an intermediate position - he acknowledges the necessity to know the health condition of a future spouse, yet he tries to preserve freedom, dignity, and independence of the human being.

According to Polish Catholic humanists, these values would jeopardise another issue proposed by the eugenics take on the man and society - sterilisation of people considered to be of less biological or social value. Motions of bills approving of sterilisation are inacceptable from the conservative Catholic perspective. Each sterilisation, especially an enforced one, which was also postulated by the eugenics circles, is treated here as "a violent invasion of the most personal of human rights" ${ }^{\prime 4}$, severe mutilation and depriving a human body of one of its vital functions. Of course, it may be allowed, but on strict medical indications only, when a lack of it puts a given person's health and life at a substantial risk ${ }^{45}$. The social criterion cannot be taken into consideration. Only God may dispose of the

40 Stanisław Podoleński, „Problem lekarskich porad i świadectw przedślubnych”. Przegląd Powszechny 204 (1934): 49.

41 Kostkiewicz, „Wychowanie”, 150-154; eadem, Kierunki, 407-413.

42 Podoleński, „Problem lekarskich”, 51. Por. Kostkiewicz, „Wychowanie”, 150-154; edem, Kierunki, 407-413.

43 Podoleński, „Projekt polskiej”, 387-393.

44 Idem, „Etyka katolicka”, 202.

45 Idem, Ustawa sterylizacyjna w Niemczech, 61. 
human life and body at his discretion ${ }^{46}$. As it has been mentioned above, from the perspective of Catholic humanists in the years 1918-1939, eugenics "ignores the spiritual, supernatural factor, which often miraculously leads individuals damned by the eugenics to the heights of human perfection" ${ }^{\prime 7}$. We cannot destroy one's chance offered them by the family, offspring, to self-perfect reach spiritual development.

But the lack of approval for sterilisation of people is supported not only with arguments referring to human nature and dignity, but also by pointing out the practical disadvantages of such a solution. The benefits of executing such a procedure are disproportionately small in comparison to expectations. In their projects, the eugenics rely on research on inheritance, but from the Catholic perspective, these had not been documented and proved sufficiently - there is no guarantee that properties considered to be bad could actually be eradicated through sterilisation and even if they could, other undesired properties would not take their place ${ }^{48}$. Therefore, a question arises what are the boundaries and criteria for application of such a procedure, while the mere existence of such procedure may not only fail to bring the expected results, but also cause irreparable moral damage and bring people and social groups to moral margins ${ }^{49}$. Especially if the promoters do not stick to methods of gentle persuasion, but enforce sterilisation upon others ${ }^{50}$. This would be acting against nature - just like in the case of various contraceptive methods and measures ${ }^{51}$. From this perspective, sterilisation means taking a step too far, it mutilates both physically as well as psychologically and morally, it does not allow for correction and prevents people, who are considered "worse" or "unnecessary" according to some vague and potentially biased criteria, from achieving perfection.

The problem of sterilisation is connected to the issues of so called conscious maternity promoted by the eugenics circles. From the eugenics point of view, this mainly consist in acceptance and promotion of use of artificial birth control methods, that is contraception and abortion. From the perspective of Catholic educators of the interwar period, both are inacceptable. Abortion is understood as genocide on a man brought to life ${ }^{52}$. A person performing abortion put himself in the position of a judge granting life or death - a role reserved for God and God only ${ }^{53}$. Conducting such a procedure, regardless whether it is legal or not, is

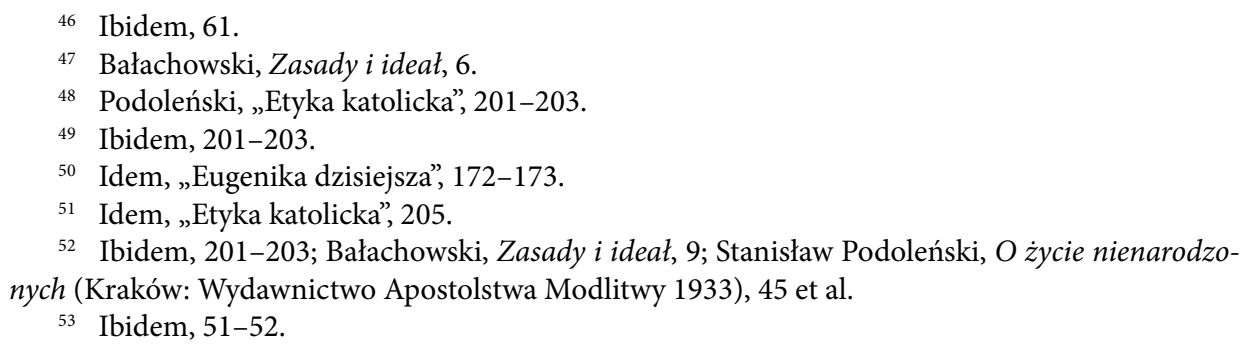


treated as a factor with a negative effect on the functioning of a catholic family ${ }^{54}$, while approval or encouraging or forcing a woman to undergo it is perceived as an action violating women's needs and interest.

Catholic educators of the interwar period perceive a wide scope of moral, social, economic, and cultural conditions within which approval for abortion emerged at that time ${ }^{55}$, but the more so, they wish to increase awareness of the procedure and its consequences. As they point out, an abortion not only results in the woman feeling guilty for killing her own child, but also putting at risk both her physical health (loss of health, fertility issues, loss of life) and moral condition $^{56}$. Abortion coexists with health-related and psychological consequences for the mother, it is often connected to extra-marital relationships, an increase in promiscuity, as well as demoralization of the entire society. This statement may be exemplified by the results of introduction divorce law and abortion rights in the Soviet Union, whose gravity contributed to restoration of limitations on abortion soon afterwards ${ }^{57}$. As we can see, approval of abortion involves negative consequences for the entire society, but, according to Catholic educators of the interwar period, women are the ones suffering the most as a result of its promotion.

From the perspective of Catholic humanists of the interwar period, the use of artificial contraceptive measures as an element of conscious maternity promoted by the eugenics movement is also perceived as a wrong and sinful solution to the issues of excessive fertility, especially among the poor. Neo-Malthusianism to which the eugenics refer, understood as limiting the number of children within a family by means of contraception, is treated as a threat to the family, because the use of artificial contraceptives serves demoralization only as allowing people to avoid the consequences of their action ${ }^{58}$ - both within and outside marriage. Promotion of contraceptives in public space or press was perceived as close to pornography, which was, in turn, considered to be one of the main enemies of marital chastity, a means to scandalized the innocent and promote promiscuity ${ }^{59}$. Contraception is easy, therefore it does not favour self-perfection, it does not help people to achieve the ultimate goal - redemption in the next life.

54 A.N., „Ku odrodzeniu”, 67; Antoni Szymański, „Podstawy polskiego prawa małżeńskiego”. Prąd 22 (1932): 3-46; Marjan Wachowski, Jakie czynniki społeczne zagrażaja rodzinie (w ujęciu negatywnem i pozytywnem) (Poznań: Drukarnia Centralna w Poznaniu 1935), 3-5.

55 Podoleński, „O życie”, 16; Władysław Wicher, „Walka o kiełkujące ludzkie życie”. Przegląd Powszechny 187 (1930): 274-277.

56 Podoleński, „Etyka katolicka”, 201-203.

57 Idem, Rodzina w Sowietach (Kraków: Wydawnictwo Apostolstwa Modlitwy 1938), 54-65; idem, „O życie”, 107-120.

58 Andrzej Niesiołowski, Franciszek Witaszek, Odkrycie dr Ogino. Rozwiązanie zagadnienia regulacji urodzin ze stanowiska katolickiego (Poznań: Drukarnia „Dziennika Poznańskiego” 1937), $11-12$.

59 Goliński, „Walka”, 313-318; Papierkowski, „Przepisy”, 94-103. 
Only sexual abstinence, permanent or temporary, was accepted by Polish humanists of the interwar period as a method for preventing conception - mainly because of its education value. Refraining from sexual intercourse was treated as an exercise in strengthening one's will and, as such, useful for self-perfection ${ }^{60}$. Artificial contraceptives, on the other hand, by separating the sexual and reproductive functions, have a negative impact on the man's moral life. They encourage for ill-understood freedom, also sexual one, may be used as an argument against marriage, a step towards an utilitarian approach to woman, treating her like a sexual object, leading to "using" another person in order to satisfied temporary urges ${ }^{61}$. It was seen as an encouragement for informal relationships or having multiple sexual partner, which was connected to a significant medical problem of the interwar period: sexually transmitted disease. According to critics of the eugenics, only true and widespread pre-marital chastity and marital faithfulness would be effective in reducing the number of STD patients ${ }^{62}$. Therefore, artificial birth control is "a crime against the child, the woman, marriage, general health and welfare of people" 63 .

Generally speaking, reaching a compromise between the eugenics principle and the Catholic standing is, from the perspective of the discussed Polish humanists of the interwar period, impossible. Acceptance of the portion of eugenics described as positive must comply with additional requirements which do not allow for excessive interference with the freedom and morality of individuals. It seems that this irreconcilable difference is related to different concepts of man forming the base of the eugenics and the Catholic social teachings, to which the above mentioned humanists refer. From the catholic perspective, eugenics is too a medical approach, materialistic and collectivists in its essence and, as such, one that does not take the spiritual and material nature of the human being and his dignity onto consideration, places the social interest above the freedom and needs of the $\operatorname{man}^{64}$. This results in postulates that, from the perspective of Catholic humanists of the interwar period, make the man equal to animals and lead to human breeding ${ }^{65}$. Such a take on the subject is contrary to the Thomist and personalist interpretation of the human nature that forms the basis of the Catholic social teachings and the detailed elaboration on thereof in educational concepts formulated by a substantial number of writers of the interwar period.

60 Niesiołowski, Witaszek, Odkrycie, 13-27. Jan Urban, „O zdrowie moralne w naszych rodzinach". Przegląd Powszechny 153/154 (1922): 433.

${ }_{61}$ Stanisław Podoleński, „W walce z poczęciem życia”. Przegląd Powszechny 205 (1935): 10-18; Urban, „O zdrowie”, 431-432.

62 Stanisław Podoleński, „W walce z zarazą”. Przegląd Powszechny 183 (1929): 241-258.

63 Podoleński, „W walce $\mathrm{z}$ poczęciem”, 18.

64 Idem, „Etyka katolicka”, 200-201.

65 Idem, „Projekt polskiej”, 387-393; Antoni Szymański, „Polskie prawo małżeńskie”. Prąd 29 (1935): 131. 
How are thus the problems discussed above related to the female issue? All the reservations made by Catholic humanists active in the years 1918-1939 on the subject of eugenics and its assumed concept of the man refer necessarily to the woman too. But arguments put forward by these authors include specific references to the female issue which might suggest that the consequences of adopting legal regulations based on the eugenics premises would have especially adverse effects on women, despite the fact that they are executed as, among others, a part of emancipation of women.

In the eyes of Polish Catholic humanists, all the above described postulates of the eugenics lead to demoralisation of the people who introduce them and the entire societies that accept them. Both the postulates of incorporation of artificial birth control methods, introduction of sterilization of the biologically or socially "lesser" ones, and introduction of sexual education that promotes these principles, advocated by the eugenics movement, as well as attempts to deploy them in the neighbouring countries ruled by totalitarian regimes, were based on an anthropological concept that is false from the Catholic perspective and their presence in the social life favours laicization and gradual demoralisation of society. And its occurrence is particularly important for women.

It is Christianity that elevated the woman's social position granting her the same rank as men - as "a creature given an immortal sold, designated for everlasting possession of God in the supernatural order" ${ }^{\prime 6}$. During the pagan times, when physical strength was more important than morality and wisdom, the woman, as more fragile, was subordinated to the $\operatorname{man}^{67}$. Making her equal to the man as far as the essence and aim of their life is concerned, as well as establishing high moral standards by Christianity, had a positive impact on her position within society and contributed to both equal treatment and respect. A process of loosening morals visible in the interwar period ${ }^{68}$, linked by Catholic humanists to the introduction of divorce law and promotion of the eugenics method of birth control, from that perspective, led to acceptance of promiscuity and weakening the role of the family. And because it was assumed that the position of the woman depends on the moral level of society, therefore that gradual demoralisation was perceived as a significant threat to the woman: "the history and practice of the divorce law showed them that this solution [...] encourages egoism and

66 Idem, Rozwód, 141.

67 Ibidem, 138-141.

68 P. Cegielska, „Kobieta wobec zepsucia obyczajów”. Przewodnik Społeczny V (1923/24): 230237; Jan Urban, „Przeciwko zarazie moralnej”. Przeglą Powszechny 143/144 (1919): 289-298; Stanisław Podoleński, „Czy zmierzch kobiety?”. Przegląd Powszechny 168 (1925): 305-318; Z. Rzepecka, „Emancypacja kobiet”. Przewodnik Społeczny XIII (1932): 26-33. 
most basic instincts [...]. As a result, it leads to a general deterioration of morality and restores the pagan relationships, with their contempt and disregard for the woman"69.

It is so because, along with the increase in amorality, the woman is treated to a larger extent as a sexual object, a tool men use to satisfy their urges. If there are no consequences, if the woman herself agrees for lowering her moral level, for negation of the basic moral principles thus she strengthens the shift towards a more utilitarian perception of her role within male-female relationship and society. But "the woman's dignity requires that she is not treated as a soulless object and turned into a simple tool of male sensuality"70. Only the woman's spiritual beauty and the society's high moral level that she, first and foremost, ensures through proper upbringing of her children, guarantees that she as a woman enjoys respect and admiration from men, social equality, and protection from humiliation $^{71}$. From that point of view, maintaining the rules of social life based on Christian principles is the best way to ensure women's freedom and equality.

Polish Catholic humanists perceive the assumption that the above mentioned freedom and equality is guaranteed by introducing the principles of practical eugenics is false. The eugenics, trying to apply these premises to social life, often support their postulates with arguments of the woman's happiness. But, form the Catholic perspective, such an understanding of happiness is false and such an interpretation of female emancipation is ill-guided. "It's often said [...] that the woman has human rights $[. .$.$] that she has the right to be happy. There are people$ ready to justify all their sinful practices in the name of this wrongly grasped right to be happy. In their blindness, they do not see that such practices are only one step away from destruction of the family and practical bolshevism. [...]. The only salvation is to restore the rules. Marital life makes sense only when the spouses believe they are tools in God's great plan"72.

\section{Conclusions}

As we can see, criticism of eugenics from the perspective of Polish Catholic humanists of the interwar period is connected to voicing acknowledgement and emphasising the women's freedom and equality within society. The eugenics principle presented from the above perspective harm this part of society in a particular manner and - often with help from the persons concerned - destroy the

69 Podoleński, Rozwód, 148

70 Urban, „O zdrowie”, 434.

71 Stanisław Podoleński, „O poszanowanie kobiety”. Przegląd Powszechny 181 (1929): 338; Urban, „O zdrowie”, 420-438.

72 J. Wędrychowska, „Kobieta katolicka wobec upadku rodziny”. Prąd 22 (1932): 310-311. 
special role of the woman in family and society contributing to demoralization of entire generations.

The presented criticism of eugenics seems to be analysing, in an unbiased and detailed manner, various assumptions that comprise the postulates of the eugenics movement. It is presented from a clearly defined perspective which is being emphasized throughout. It seems to be built with the future of the Polish society in mind and out of fear of the consequences resulting from adoption of the eugenics principles, which, at that time, had already been evident in the Nazi Germany and the Communist Soviet Union. It has historical value and reveals the described social, political, and cultural context that accompanied Polish humanists of the interwar period. But at the same time, it remains valid in many aspects, because it takes note of hazards resulting from gullibility and lack of thorough consideration in following mental trends.

\section{Eugenika a kwestia kobieca w myśli wybranych polskich humanistów katolickich z lat 1918-1939}

Streszczenie: Tak, jak w I połowie XX wieku rozpowszechnione było myślenie oparte o założenia eugeniczne, tak również rozpowszechniona była jego krytyka. W części pochodziła ona z przyjmowania pespektywy Kościoła katolickiego przez humanistów, pedagogów, którzy w odniesieniu do nauki społecznej Kościoła budowali swoje koncepcje pedagogiczne. Celem niniejszego artykułu jest pokazanie podstawowych elementów krytyki stanowiska eugeników z punktu widzenia polskich pedagogów katolickich z lat 1918-1939. Krytyka ta istniała, podnosiła podstawowe wątki charakterystyczne dla stanowiska Kościoła katolickiego, ale prowadzono ją m.in. - co interesujące - z punktu widzenia „interesów” kobiety. Wprowadzenie zasad eugeniki, choć w środowiskach ją aprobujących było przedstawiane jako sposób emancypacji, w opisywanym środowisku traktowano jako drogę do demoralizacji i degradacji kobiety jako osoby.

Słowa kluczowe: eugenika, pedagogika katolicka, kobieta, kwestia kobieca, dwudziestolecie międzywojenne

\section{Bibliography}

A.N. „Ku odrodzeniu rodziny”. Przewodnik Społeczny 2 (1929): 65-72.

Bałachowski, Witold. Zasady i ideał wychowania rodzinnego. Poznań: Czcionkami Drukarni Wydawniczej Fr. Krajna Spółka z ó. o. w Poznaniu, 1937.

Bołdydrew, Aneta. „Wpływ maltuzjanizmu i neomaltuzjanizmu na rozwój myśli eugenicznej na przełomie XIX i XX wieku”. In: Eugenika - aspekty społeczne i etyczne, ed. Michał Musielak, Krzysztof Prętki, 11-25. Poznań: Uniwersytet Medyczny im. Karola Marcinkowskiego w Poznaniu, 2013.

Gawin, Magdalena. Rasa i nowoczesność. Historia polskiego ruchu eugenicznego. Warszawa: Wydawnictwo Neriton, Instytut Historii PAN 2003.

Goliński, Zdzisław. „Walka Kościoła z pornografią”. Prąd 36 (1938): 304-320. 
Kostkiewicz, Janina. „Wychowanie prorodzinne w myśli społeczno-pedagogicznej ks. Stanisława Podoleńskiego TJ”. In: Społeczeństwo, kultura, wychowanie w poglądach polskich jezuitów okresu II Rzeczypospolitej, ed. Stanisław Cieślak SJ, Beata Topij-Stempińska, 141-168. Kraków: Wydawnictwo WAM, Akademia Ignatianum w Krakowie, 2012.

Kostkiewicz, Janina. Kierunki i koncepcje pedagogiki katolickiej w Polsce 1918-1939. Kraków: Oficyna Wydawnicza „Impuls”, 2013.

Musielak, Michał. Sterylizacja ludzi ze względów eugenicznych w Stanach Zjednoczonych, Niemczech i w Polsce (1899-1945). Poznań: Wydawnictwo Poznańskie, 2008.

Niesiołowski, Andrzej, Witaszek, Franciszek. Odkrycie dr Ogino. Rozwiązanie zagadnienia regulacji urodzin ze stanowiska katolickiego. Poznań: Drukarnia „Dziennika Poznańskiego”, 1937.

Niesiołowski, Andrzej. „Kryzys rodziny nowoczesnej i jego przyczyny”. In: Rodzina. Pamiętnik I Katolickiego Studium o Rodzinie w Poznaniu, w dn. 2-6 września 1935. Poznań: NIAK 1936.

Papierkowski, Zdzisław. „Przepisy prawne dotyczące pornografii”. Prąd 37 (1939): 94-103.

Pius XI, Casti Conubii, avaible online (access: 15 III 2018), http://www.nonpossumus.pl/encykliki/ Pius_XI/casti_connubii/II.php

Pius XI, Divini Illius Magistri, avaible online (access: 15 III 2018), http://www.nonpossumus.pl/ encykliki/Pius_XI/divini_illius_magistri/IV.php

Platon. Państwo. Kęty: Wydawnictwo Marek Derewiecki, 2009.

Podoleński, Stanisław. „Czy zmierzch kobiety?”. Przegląd Powszechny 168 (1925): 305-318.

Podoleński, Stanisław. „Etyka katolicka a eugenika i medycyna”. Przegląd Powszechny 214 (1937): 195-208.

Podoleński, Stanisław. „Eugenika dzisiejsza, jej drogi i bezdroża”. Przegląd Powszechny 194 (1932): 166-186.

Podoleński, Stanisław. „Eugenika i ruch eugeniczny”. Przegląd Powszechny 579 (1932): 319-331.

Podoleński, Stanisław. „O poszanowanie kobiety”. Przegląd Powszechny 181 (1929): 333-348.

Podoleński, Stanisław. „Problem lekarskich porad i świadectw przedślubnych”. Przegląd Powszechny 204 (1934): 45-63.

Podoleński, Stanisław. „Projekt polskiej Ustawy Eugenicznej”. Przegląd Powszechny 204 (1934): 387-393.

Podoleński, Stanisław. „Ustawa sterylizacyjna w Niemczech”. Przegląd Powszechny 201 (1934): 46-67.

Podoleński, Stanisław. „W walce z poczęciem życia”. Przegląd Powszechny 205, (1935): 3-23.

Podoleński, Stanisław. „W walce z zarazą”. Przegląd Powszechny 183 (1929): 241-258.

Podoleński, Stanisław. „Wychowanie seksualne młodzieży i przygotowanie do małżeństwa”. In: Wychowanie chrześcijańskie jako problem duszpasterski (praca zbiorowa). Kielce: Nakładem „Przeglądu Homiletycznego", 1934.

Podoleński, Stanisław. O życie nienarodzonych. Kraków: Wydawnictwo Apostolstwa Modlitwy, 1933.

Podoleński, Stanisław. Rodzina w Sowietach. Kraków: Wydawnictwo Apostolstwa Modlitwy, 1938.

Podoleński, Stanisław. Rozwód a zdrowie narodu. Kraków: 1926.

Rzepecka, Z. „Emancypacja kobiet”. Przewodnik Społeczny XIII (1932): 26-33.

Strządała, Agata. Od Galtona do Watsona. Przemiany pojmowania eugeniki w XIX i XX wieku. Opole: Uniwersytet Opolski 2010.

Szymański, Antoni. „Podstawy polskiego prawa małżeńskiego”. Prąd 22 (1932): 3-46.

Szymański, Antoni. „Polskie prawo małżeńskie”. Prąd 29 (1935): 115-132.

T.Cz. „Zagadnienia seksualne w życiu religijnym”. Miesięcznik Katechetyczny $i$ Wychowawczy XXV (1936): 202-214. 
Urban, Jan. „O zdrowie moralne w naszych rodzinach”. Przegląd Powszechny 153/154 (1922): $420-438$.

Urban, Jan. „Przeciwko zarazie moralnej”. Przegląd Powszechny 143/144 (1919): 289-298.

Wachowski, Marjan. Jakie czynniki społeczne zagrażaja rodzinie (w ujęciu negatywnem i pozytywnem?). Poznań: Drukarnia Centralna w Poznaniu, 1935.

Weryński, Henryk. Na progu uświadomienia. Wskazówki dla matek i wychowawców. Poznań - Warszawa - Wilno - Lublin: Nakład Księgarni Św. Wojciecha, 1930.

Wędrychowska, J. „Kobieta katolicka wobec upadku rodziny”. Prąd 22 (1932): 308-316.

Wicher, Władysław. „Walka o kiełkujące ludzkie życie”. Przegląd Powszechny 187 (1930): 261-277.

Zaremba Bielawski, Maciej. Higieniści. Z dziejów eugeniki. Wołowiec: Wydawnictwo Czarne 2011. 